\title{
Using social-ecological systems theory to evaluate large-scale comanagement efforts: a case study of the Inuvialuit Settlement Region
}

\author{
William Tyson $^{1}$
}

\begin{abstract}
Comanagement efforts are increasingly tasked with overseeing natural resource governance at a large scale. I examine comanagement of subsistence harvesting in the Inuvialuit Settlement Region (ISR) of the western Canadian Arctic, using a socialecological systems framework. In doing so, this study joins a growing list of research that reviews design principles commonly found in successful small-scale commons management and applies them to a large resource area. This research uses the management of beluga (Delphinapterus leucas) and barren-ground caribou (Rangifer tarandus groenlandicus) as case studies in understanding the management framework of the Inuvialuit Settlement Region, as each species is important in Inuvialuit culture and is actively managed and monitored. Comanagement bodies in the study area display many of the institutional design principles that are characteristic of successful socialecological systems. Particularly mentionable are the presence of well-organized nested enterprises and a strong incorporation of local knowledge and monitoring. This supports the application of institutional design principles in large-scale analyses of resource management. However, due to the network of policy and management outside the ISR that influences each species, this research suggests that in cases of wide-ranging resource bases, these types of analyses may be better suited to evaluating broad management networks rather than discrete governing regions.
\end{abstract}

Key Words: common pool resources; Elinor Ostrom design principles; Inuvialuit Settlement Region; social-ecological systems

\section{INTRODUCTION}

Comanagement is typically defined as a sharing of power and decision-making responsibility between local resource users and a larger government entity (Carlsson and Berkes 2005). Comanagement efforts between state governments and local land users are becoming increasingly prevalent in an attempt to better integrate local knowledge and land use priorities with natural resource management (Berkes 2009). This is especially true in northern Canada, where the federal government's recognition of Aboriginal title in the 1970 s prompted a series of land claim agreements that recognize indigenous land use rights and provide a framework for power-sharing and cooperative governance of natural resources (Berkes and Fast 2005). As a result, scientists, land managers, and indigenous communities in the Canadian Arctic and subarctic are often tasked with cooperatively overseeing natural resource policy that governs large tracts of land (Berkes 1999, Fast 2005). While the cooperative governance of large territories is increasingly practiced, common-pool resource theory has noted that as the size of the resource base increases, difficulties such as a mismatch in scale or the presence of unclear boundaries may limit the effectiveness of these largescale social-ecological systems (SESs) (Ostrom 1990, Berkes 2006, Cox et al. 2010).

Recent research has focused on using frameworks typically found in small-scale common-pool resources, such as local fisheries or timber harvesting, to evaluate large environmental issues such as atmospheric pollution, migratory fish harvests, governance of large conservation areas, or watershed management (Pollnac et al. 2010, Cox 2014, Fleischman et al. 2014, Lacroix and Richards 2015). These efforts are based on Elinor Ostrom's SES framework (Ostrom 2009) and design principles for community-based natural resource management (Ostrom 1990, Cox et al. 2010). The SES framework guides the systematic evaluation of the governance of common-pool natural resources by considering interactions between the governance system, the resource system, actors, and external social and ecological influences. The framework recognizes that successful management of commonpool resources involves a diverse range of social and ecological factors, such as the capacity for users to self-organize (social) or the biophysical range of the resource in question (ecological) (Ostrom 2009).

The SES framework emerged in part from Ostrom's previous work on institutional analysis (Ostrom 1990), which included the identification of characteristics commonly present in longenduring, small-scale institutions for natural resource management (so-called design principles). The institutional design principles (Table 1) include the presence of clearly defined boundaries, congruence between restrictions and local conditions, congruence between inputs and local conditions, collective choice arrangements, active monitoring, accountable monitoring, graduated sanctions, conflict-resolutions mechanisms, recognition of the rights to organize, and the presence of nested enterprise (Cox et al. 2010). Both institutional design principles and the SES framework have emerged from, and been applied predominantly to, small-scale systems (Ostrom 2009, Cox et al. 2010), and a relatively new field of research asks if these variables can be applied to the analysis of large environmental systems (Cox 2014).

The research presented in this article contributes to efforts that test the applicability of institutional design principles on a large scale by attempting to identify the presence of Ostrom's (2009) and Cox et al.'s (2010) design principles in order to evaluate comanagement of wildlife resources in the Inuvialuit Settlement Region (ISR) in the western Canadian Arctic. Created in 1984 with the signing of the Inuvialuit Final Agreement (IFA), the ISR covers $906,430 \mathrm{~km}^{2}$. It is composed of six small communitiesInuvik, Aklavik, Tuktoyaktuk, Paulatuk, Sachs Harbour, and 
Ulukhaktok - and supports a suite of important marine and terrestrial wildlife that are relied on for hunting, trapping, whaling, and fishing (Berkes and Jolly 2001, Alunik et al. 2003, Pearce et al. 2011). Both marine and terrestrial species are routinely harvested by the Inuvialuit (Harwood et al. 2002, Alunik et al. 2003, Joint Secretariat 2003), and serve as culturally, nutritionally, and economically important resources in a region that has few wage-earning opportunities and minimal options for store-bought foods (Schlag and Fast 2003, GNWT 2008, Andrachuk and Smit 2012). As a component of Inuvialuit occupancy, the IFA provides a framework for comanagement of wildlife harvesting in the ISR (Department of Indian and Northern Affairs Canada 1984).

Table 1. Design principles and their definition, as described by Cox et al. (2010).

\begin{tabular}{|c|c|}
\hline Design principle & Description \\
\hline 1A. Clearly defined boundaries & $\begin{array}{l}\text { The users who are allowed to draw } \\
\text { from the common pool resource } \\
\text { are clearly defined. }\end{array}$ \\
\hline 1B. Clearly defined boundaries & $\begin{array}{l}\text { The common pool resource itself } \\
\text { must be clearly defined. }\end{array}$ \\
\hline $\begin{array}{l}\text { 2A. Congruence between } \\
\text { appropriation and provision rules } \\
\text { and local conditions }\end{array}$ & $\begin{array}{l}\text { The conditions of the common } \\
\text { pool resource must warrant the } \\
\text { restrictions that are placed on its } \\
\text { use. }\end{array}$ \\
\hline $\begin{array}{l}\text { 2B. Congruence between } \\
\text { appropriation and provision rules } \\
\text { and local conditions }\end{array}$ & $\begin{array}{l}\text { The benefits received by users of } \\
\text { the common pool resource are } \\
\text { proportional to the inputs required } \\
\text { for resource management. }\end{array}$ \\
\hline 3. Collective choice arrangements & $\begin{array}{l}\text { Most individuals who are affected } \\
\text { by the state of the common pool } \\
\text { resource can impact its operational } \\
\text { rules. }\end{array}$ \\
\hline 4A. Monitoring & Monitors are present and active. \\
\hline 4B. Monitoring & Monitors are accountable. \\
\hline 5. Graduated sanctions & $\begin{array}{l}\text { Users of the common pool } \\
\text { resource who violate operational } \\
\text { rules are sanctioned proportionally } \\
\text { to the severity of their violation. }\end{array}$ \\
\hline 6. Conflict resolutions mechanisms & $\begin{array}{l}\text { Resource users and managers have } \\
\text { accessible arenas for resolution of } \\
\text { conflict. }\end{array}$ \\
\hline $\begin{array}{l}\text { 7. Recognition of rights to } \\
\text { organize }\end{array}$ & $\begin{array}{l}\text { External government authorities } \\
\text { do not challenge the rights of users } \\
\text { and managers to operate their own } \\
\text { institutions. }\end{array}$ \\
\hline 8. Nested enterprises & $\begin{array}{l}\text { Resource use, management, } \\
\text { monitoring, and conflict } \\
\text { resolutions are organized in } \\
\text { multiple, nested layers. }\end{array}$ \\
\hline
\end{tabular}

To explore governance of wildlife resources in the region, I focus on the management of barren-ground caribou (Rangifer tarandus groenlandicus) and beluga (Delphinapterus leucas). Each is a major terrestrial or marine species of importance, respectively (Alunik et al. 2003), and is harvested in large numbers by Inuvialuit communities (Usher 2002, Joint Secretariat 2003). The importance of each species is reflected in a host of management and research activity, both in the ISR and regionally (Adams et al. 1993, FJMC 2001, Gunn et al. 2011, Advisory Committee for the Cooperation on Wildlife Management 2014a). While an extensive history of transboundary management efforts surrounds both species, this analysis is restricted to internal governing structures in the ISR. This research does not attempt to evaluate the biological success of management or the efficacy of transboundary initiatives, but it uses caribou and beluga management as focal points in an effort to identify the presence of institutional design principles within ISR comanagement and to provide further evidence of the usefulness of design principles in understanding large-scale common resources.

\section{METHODS}

Analysis was based on a literature review of major academic research in the region, as well as management decisions and government framework of the ISR. I conducted a review of relevant case studies in the region, based on common phrases and keywords in literature surrounding Inuvialuit harvest management (Table 2), and attempted to identify relationships between the state of a resource and its surrounding governance structure in a manner similar to previous SES analysis (Fleischman et al. 2014). Sources were categorized based on their demonstration of design principles. I noted instances in which government documents or grey literature explicitly described a design principle (i.e., demarcating the nested governing structure of the region). Academic research was reviewed for descriptions of processes or events that reflected the presence of design principles (e.g., a report on the growing incorporation of local knowledge in species management would be noted as representing congruence between inputs and local conditions, as well as active monitoring).

\section{BACKGROUND ON FOCAL RESOURCES}

Wildlife harvesting is an essential part of Inuvialuit subsistence culture, and while harvesting patterns vary across the study region, caribou and beluga represent the major terrestrial and marine species of importance, respectively (Usher 2002, Alunik et al. 2003). Individual communities' harvest patterns tend to be determined by their proximity to terrestrial or marine habitats, but at a broad scale, caribou and beluga are major harvested species in the ISR, both in terms of the size of harvest (Usher 2002, Joint Secretariat 2003) and cultural importance (Alunik et al. 2003). As such, each species is the subject of research and policy action, both within the ISR and in the greater region, that is meant to ensure a sustainable harvest (Adams et al. 1993, FJMC 2001, Harwood et al. 2002, Environment and Natural Resources 2011).

Beluga harvesting traditionally occurred among Inuvialuit groups that had access to summer harvesting waters (Harwood and Smith 2001) where beluga return each year (Harwood and Smith 2001, Harwood et al. 2002). Inuvialuit harvesting continues each summer, mainly when portions of the stock concentrate in the Mackenzie River Estuary, which is typically accessed by the communities of Inuvik, Aklavik, and Tuktoyaktuk; however, the community of Paulatuk also participates in their own beluga harvest, and residents of Ulukhaktok and Sachs Harbour may occasionally harvest beluga, as well (FJMC 2001, Harwood and Smith 2001).

Caribou were traditionally harvested for both meat and fur (Alunik et al. 2003). Multiple separate caribou herds exist, at least partially, within the region (Environment and Natural Resources 
Table 2. Key search terms used in the literature review.

\begin{tabular}{ll}
\hline \hline Topic & Search terms \\
\hline $\begin{array}{l}\text { Inuvialuit Settlement Region } \\
\text { governing structure }\end{array}$ & $\begin{array}{l}\text { Inuvialuit Settlement Region, Joint Secretariat, Inuvialuit comanagement, Inuvialuit Final Agreement, } \\
\text { Mackenzie Delta comanagement } \\
\text { Inuvialuit land use/knowledge }\end{array}$ \\
$\begin{array}{l}\text { Inuvialuit subsistence harvesting, Inuvialuit traditional ecological knowledge, wildlife management Mackenzie } \\
\text { Delta }\end{array}$ \\
$\begin{array}{l}\text { Arctic climate change, Mackenzie Delta climate change, Inuvialuit climate change adaptation } \\
\text { environmental issues }\end{array}$ \\
$\begin{array}{l}\text { Species-specific management/ } \\
\text { outcomes }\end{array}$ \\
\hline
\end{tabular}

2011), and the species is currently harvested by all communities;, however, major herd ranges occur on the mainland, and harvest levels are highest among residents of Inuvik, Aklavik, Tuktoyaktuk, and Paulatuk (Joint Secretariat 2003, Advisory Committee for the Cooperation on Wildlife Management 2014a, b).

\section{HARVEST MANAGEMENT AS A SOCIAL-ECOLOGICAL SYSTEM}

\section{Governance system}

The guiding document for the governance of the ISR is the Inuvialuit Final Agreement (IFA). Signed in 1984, the IFA was a result of recommendations put forth by a regional task force that called for increased conservation planning and management in the face of growing development pressure from the oil industry (Fast et al. 2005). It gave the Inuvialuit land ownership, financial compensation, and participation in wildlife management, as well as an avenue to influence development on Crown land through commenting on environmental impact assessments (Department of Indian and Northern Affairs Canada 1984, Fast et al. 2005, Andrachuk and Smit 2012). The IFA's three basic goals, as agreed upon by the Inuvialuit and Canada (Department of Indian and Northern Affairs Canada 1984), are:

- to preserve the Inuvialuit and values within a changing northern society;

- to enable the Inuvialuit to be equal and meaningful participants in the northern and national economy and society; and

- to protect and preserve the Arctic wildlife, environment, and biological productivity.

In order to achieve theses goals as they relate to wildlife, the IFA provides for the creation of the Inuvialuit Game Council, the Wildlife Management Advisory Council, and the Fisheries Joint Management Council (FJMC), as well as community-level Hunter Trapper Committees (HTCs) in an effort to regulate and maintain healthy populations of harvested species throughout the ISR (Table 3). While this arrangement does not result in selfgovernment, a continued pursuit of the Inuvialuit, it does allow for meaningful input in the political process, a strong Inuvialuit voice in development decisions, and a means of seeking compensation for damages that occur to land within the ISR (Pearce et al. 2011). In doing so, the IFA clearly defines the geographic and user boundaries for wildlife harvesting in the ISR, and provides the framework for a nested hierarchical approach toward harvest management (Table 4).

\section{Nested hierarchical organization of actor groups}

The governance of subsistence harvesting in the ISR is conducted at multiple scales by multiple sets of actors. Fundamentally, Inuvialuit subsistence practices drive the harvesting and management of caribou and beluga. However, decision-making is carried out in a nested hierarchal fashion, with increasing jurisdiction among higher functioning governing bodies (Table 3 ). Thus, the presence of design principles can be assessed beginning at the community level and then examined through multiple comanagement bodies.

At the community level, a high dependence on wildlife harvesting informs caribou and beluga management (Fig. 1). Inuvialuit culture is heavily dependent on caribou and beluga harvesting, which creates an incentive for proper management and sustained harvesting in the ISR (Usher 2002). Local observations and knowledge emerge directly from subsistence harvesting and inform research and management initiatives (Department of Indian and Northern Affairs Canada 1984, Harwood et al. 2002, Cobb et al. 2008, Environment and Natural Resources 2011). In some cases, subsistence harvesting contributes directly to scientific research (Bell and Harwood 2012). In turn, local HTCs play an advisory role in ensuring that harvest activity is carried out in a responsible and culturally appropriate manner (Day 2002).

At a higher level, the Inuvialuit organize into actor groups to influence comanagement of the region. These groups display both upward and downward vertical linkages, as HTCs coordinate with higher comanagement bodies, while remaining tasked with implementing regional decisions at a local level (Fig. 1). Additionally, cooperation between local HTCs and more regional governance bodies results in the formation of policy that is representative of local conditions. For example, the Beaufort Sea Beluga Management Plan is the result of a coordinated effort between local HTCs and the FJMC (FJMC 2001).

The other major actors in managing the harvest of subsistence resources are the territorial and national governments. NonAboriginal appointees sit on the major regional committees and have strong input in decision-making (Department of Indian and Northern Affairs Canada 1984), and the Canadian government maintains jurisdiction over offshore environments in the ISR (Fidler and Noble 2013). Over time, interactions between actor groups have included conflicts over management priorities, the incorporation of indigenous knowledge and practices, and the role of scientific monitoring (Fast et al. 2005, Kofinas 2005, Kocho-Schellenberg and Berkes 2015). However, there is an 
Fig. 1. Vertical linkages between actors in the Inuvialuit Settlement Region. Information flows in both directions as community wildlife harvesters contribute observations and concerns to Hunter Trapper Committees and higher level management bodies, which establish policy and management quotas based on multiple sources of information.

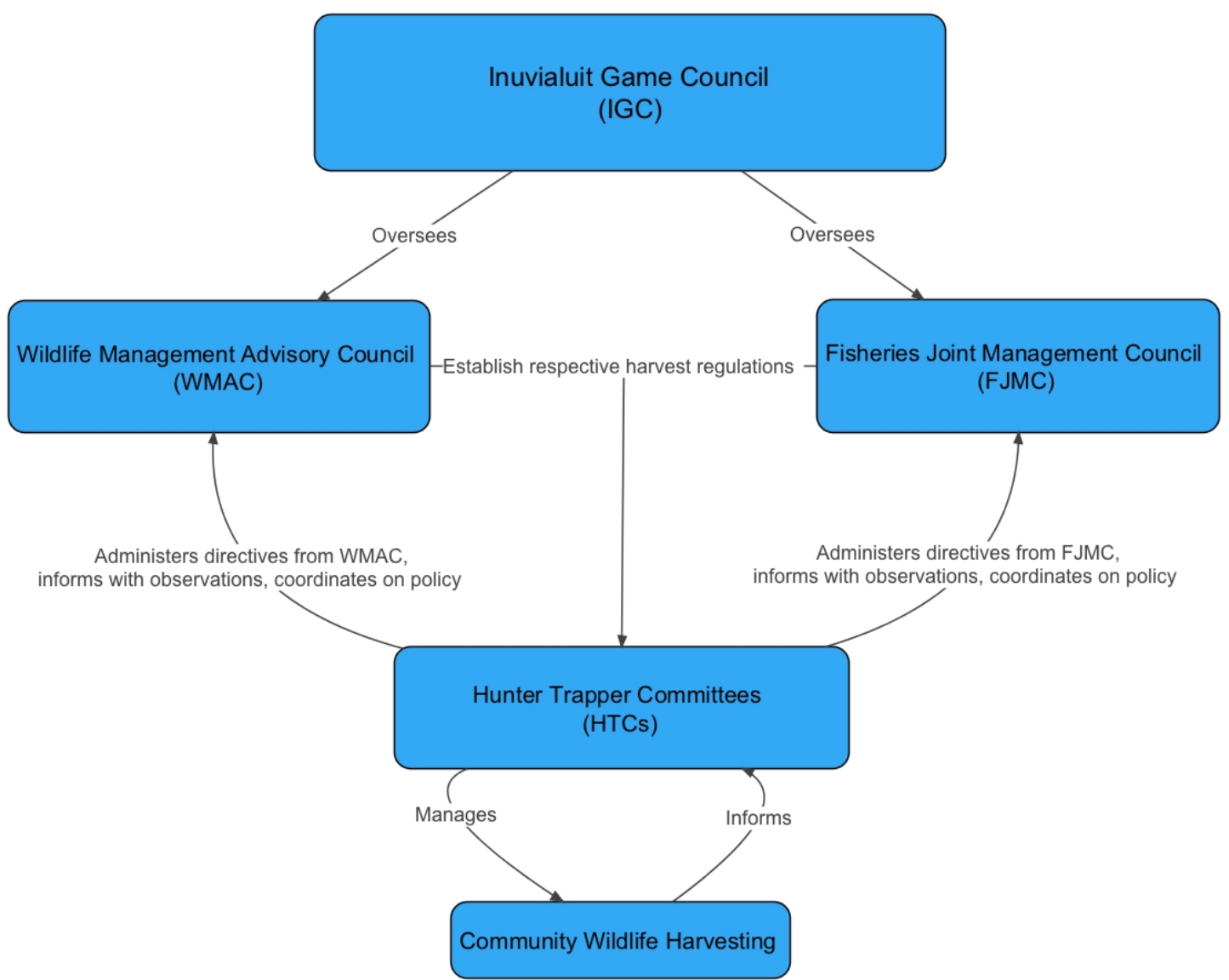

increasing effort to meaningfully incorporate local knowledge and priorities, especially in instances where the long-term experience of indigenous land users provides expert insight that is lacking in scientific literature (Fast et al. 2005, Krupnik and Ray 2007, Kocho-Schellenberg and Berkes 2015). Additionally, scientific monitoring approaches, such as repeat aerial photography, radio collaring, and harvest studies, are used to further identify trends in species health and to complement Inuvialuit knowledge (Harwood et al. 2002, Nagy and Johnson 2006, Environment and Natural Resources 2011). The strong presence of both scientific and indigenous monitoring, as well as the clear response to concerns regarding species health suggest that the nested hierarchical management structure in the ISR allows for the strong presence of further design principles, including active and accountable monitoring and congruence between local conditions and user restrictions (Table 4).

\section{External actors}

Within the ISR, pressure exists from development interests that may impact wildlife habitat. Since the 1960s, significant hydrocarbon development has occurred in the region, with recent pressure to build a major pipeline (Fast et al. 2005, Burn and Kokelj 2009). Recently, the Mackenzie Gas Project has reignited debate over the future of the region. Hydrocarbon exploration in the region has the potential to significantly benefit regional economies and the Inuvialuit are part of an Aboriginal development group, which has an ownership stake in any proposed development (Nuttall 2006). However, the cumulative effects of landscape change in the region have yet to be fully quantified, and significant concern exists regarding the long-term future of the landscape, wildlife, and traditional practices in the region (Nuttall 2006, Bennett 2012, Advisory Committee for the Cooperation on Wildlife Management 2014b). While consultation exists between comanagement bodies and the development sector (Department of Indian and Northern Affairs Canada 1984, Fast et al. 2005), there is no explicit avenue for directly influencing development activity. A host of scientific research within the region and nearby areas has documented significant impacts on caribou following industrial development (Nellemann and Cameron 1998, Johnson et al. 2005, Environment and Natural Resources 2011, Gunn et al. 2011), and cumulative effects of human activity continue to be a management concern 
Table 3. Nested governing bodies and their presence in the Inuvialuit Settlement Region (ISR) (Department of Indian and Northern Affairs Canada 1984).

\begin{tabular}{|c|c|c|c|}
\hline Management body & Membership & Jurisdiction & Purpose \\
\hline Inuvialuit Game Council (IGC) & $\begin{array}{l}\text { One Chairman of the Council, } \\
\text { representing Canada; two } \\
\text { Northwest Territories (NWT) } \\
\text { representatives; three Inuvialuit } \\
\text { representatives }\end{array}$ & $\begin{array}{l}\text { All Inuvialuit interests in } \\
\text { wildlife }\end{array}$ & $\begin{array}{l}\text { Appoint Inuvialuit representatives } \\
\text { to wildlife comanagement bodies }\end{array}$ \\
\hline $\begin{array}{l}\text { Wildlife Management Advisory } \\
\text { Council }\end{array}$ & $\begin{array}{l}\text { One Chairman of the Council, } \\
\text { representing Canada; two NWT } \\
\text { representatives; three Inuvialuit } \\
\text { representatives }\end{array}$ & $\begin{array}{l}\text { Portion of the ISR that lies } \\
\text { within the NWT, including } \\
\text { adjacent shore and offshore } \\
\text { waters }\end{array}$ & $\begin{array}{l}\text { Advise wildlife management } \\
\text { boards in the Western Arctic, } \\
\text { determine Inuvialuit harvesting } \\
\text { quotas, recommend native quotas } \\
\text { for migratory species, review any } \\
\text { proposals that affect wildlife }\end{array}$ \\
\hline $\begin{array}{l}\text { Fisheries Joint Management } \\
\text { Council }\end{array}$ & $\begin{array}{l}\text { Two representatives of Canada, } \\
\text { two Inuvialuit representatives }\end{array}$ & ISR fisheries & $\begin{array}{l}\text { Advise Minister of Fisheries on } \\
\text { matters related to the ISR, review } \\
\text { state of fisheries, determine harvest } \\
\text { levels, regulate fishing rights, } \\
\text { allocate quotas }\end{array}$ \\
\hline Hunter Trapper Committees & $\begin{array}{l}\text { Local community members from } \\
\text { each of the five Inuvialuit } \\
\text { settlement regions }\end{array}$ & Respective communities & $\begin{array}{l}\text { Advise the IGC on all matters } \\
\text { related to respective communities, } \\
\text { and allocate quotas within area of } \\
\text { responsibility }\end{array}$ \\
\hline
\end{tabular}

Table 4. Design principles (Cox et al. 2010) and their presences in the Inuvialuit Settlement Region (ISR) (Department of Indian and Northern Affairs Canada 1984). NA indicates not enough information to determine the presence of a design principle in the study area.

\begin{tabular}{lll}
\hline \hline Design principle & Presence in ISR & References \\
\hline Clearly defined user boundaries & $\begin{array}{l}\text { Inuvialuit Final Agreement (IFA) defines } \\
\text { Inuvialuit residents } \\
\text { Exclusive or preferential harvest rights for }\end{array}$ & $\begin{array}{l}\text { Department of Indian and Northern Affairs } \\
\text { Canada 1984 }\end{array}$ \\
& &
\end{tabular}

Clearly defined geographic boundaries IFA identifies the settlement region and Department of Indian and Northern Affairs notes all communities under its jurisdiction; Canada 1984, Adams et al. 1993, Kofinas 2005 however, harvested species are often migratory and extend beyond ISR boundaries

Congruence between restrictions and local Caribou hunting restrictions respond to conditions

Congruence between user inputs and local conditions

Collective-choice arrangements

Active monitoring

Accountable monitoring

Graduated sanctions

Conflict resolution mechanisms

Recognition of rights to organize

Nested enterprises decline $\dagger$ allocate harvest quotas

NA actors can inform larger management bodies conditions and species health

Frequent biological and observational

Voluntary bans on indigenous caribou harvest

NA

Yes local concern and observation of caribou

Local Hunter Trapper Committees (HTCs)

No direct collective-choice avenues, but Department of Indian and Northern Affairs clearly established processes by which local Canada 1984, Harwood et al. 2002, Cobb et al.

Department of Indian and Northern Affairs Canada 1984, Andrachuk and Smit 2012

Biophysical monitoring of environmental

$$
2011
$$
reports on caribou and beluga populations

Armitage et al. 2011, Bell and Harwood 2012, Kocho-Schellenberg and Berkes 2015

Armitage et al. 2011, Bell and Harwood 2012, Kocho-Schellenberg and Berkes 2015

Andrachuk and Smit 2012

Assumed, as part of Canadian democratic society

Higher governing bodies informed by local Department of Indian and Northern Affairs HTCs

Local HTCs tasked with implementing higher management decisions

$\dagger$ Environment and Natural Resources 2011 
in the region (Environment and Natural Resources 2011). The Beaufort Sea is largely unimpacted compared to other Canadian waters and includes special management zones that take beluga populations into consideration; however, major hydrocarbon reserves exist in the region, and there are concerns regarding the impact of future exploration and extraction on marine species, including beluga (Cobb et al. 2008).

Additionally, broad-scale climatic change threatens wildlife resources and subsistence harvesting in the region. A warming climate has been well documented to threaten the stability of the region (Cohen 1997, Corell 2006, Krupnik and Ray 2007, Cobb et al. 2008, Pearce et al. 2009, Burn and Kokelj 2009), and both beluga and caribou may face decreased food security as a result of broad-scale climate change (Berkes and Jolly 2001, Carter and Nielsen 2011). Inuvialuit Settlement Region communities have already begun noticing changes in their own food security, the health of game animals, and the ability to access hunting sites due to a changing climate, and subsistence harvesting increasingly requires adaptation to new environmental conditions (Berkes and Jolly 2001, Pearce et al. 2010, 2011).

The wide-ranging nature of both species necessitates transboundary networks that include Inuvialuit interests but extend beyond the realm of local comanagement. In the case of beluga, hunters and comanagement bodies in the ISR work with Alaskan indigenous communities and government representatives to promote sustainable harvesting of beluga, share observations and data, and agree upon transboundary management policy (Adams et al. 1993). The Inuvialuit Inupiat Beaufort Sea Beluga Whale Agreement (2000) recognizes the shared importance of the Beaufort Sea Stock to both Inuvialuit communities and northern Alaskan indigenous communities, and provides a platform for shared information and management. Inuvialuit caribou management is also largely influenced by regional policy and working groups, and Inuvialuit representatives have been involved in major planning efforts that include indigenous neighbors in both Alaska and Canada (Kofinas 2005, Advisory Committee for the Cooperation on Wildlife Management 2014a), as regional response to changing herd dynamics across the Northwest Territories (NWT) place Inuvialuit knowledge and priorities alongside those of other communities in an effort to better manage the species (Environment and Natural Resources 2011).

\section{State of the resources}

\section{Beluga}

Recent biological analyses of the beluga population have deemed the species secure in Canada (Working Group on the General Status of NWT Species 2011). A low harvest rate, combined with a hunter preference for adult males (which have usually already contributed offspring to the system) creates a sustainable harvesting practice - a conclusion supported by the continued return of large, healthy beluga to Inuvialuit hunting areas (Harwood et al. 2002). Meanwhile, recent research shows a growing incorporation of local knowledge and a strong Inuvialuit interest in beluga populations (Armitage et al. 2011, KochoSchellenberg and Berkes 2015). Over time, the presence of Inuvialuit management institutions has improved communication with researchers in the region, and local knowledge and values are well represented in beluga management (Kocho-Schellenberg and Berkes 2015). Still, Inuvialuit harvest of beluga faces a range of external factors that are difficult to control through governance, including a growing tourist presence in the region, climatic factors, and a cultural shift resulting in a decrease in harvesting (Dressler et al. 2001, Harwood and Smith 2001, Usher 2002).

\section{Caribou}

Barren-ground caribou across the Northwest Territories are considered sensitive (Working Group on the General Status of NWT Species 2011); however, multiple herds with overlapping home ranges exist within the ISR, and it can be difficult to calculate total herd size or population health for the study region. Populations are likely affected by a combination of multiple stressors, including industrial development, climate change, and natural cycles (Adamczewski et al. 2009, Environment and Natural Resources 2011), and in some instances, Inuvialuit have placed voluntary bans on caribou hunting (Andrachuk and Smit 2012). Major debate has occurred between indigenous groups and researchers in the past regarding the role of biological research and best management practices; however, better integration of indigenous and biological approaches into herd management is improving (Kofinas 2005, Advisory Committee for the Cooperation on Wildlife Management 2014b). Thus, while wildlife comanagement may succeed in monitoring caribou populations and adjusting harvest levels, caribou hunting is dependent on larger factors that are often beyond the scope of the governing bodies, and management directives are not cure-all solutions for harvest security.

\section{DISCUSSION}

\section{Design principles in the Inuvialuit Settlement Region}

Wildlife comanagement in the ISR exhibits multiple design principles that are indicative of long-enduring institutions (Table 4). Knowledgeable and active user groups, incorporation of local observations in monitoring, and nested enterprises with strong linkages are clearly present in the region. The presence of an effective and accountable monitoring system and information sharing at a local level can result in a successful large-scale governance system (Fleischman et al. 2014), and the active role of community HTCs and local resource users in the ISR may play a large role in promoting successful comanagement across the region. This supports research that analyzes large-scale SESs using institutional design principles (Cox 2014, Fleischman et al. 2014). However, analyzing the structure of wildlife harvesting in the ISR alone does not completely address the framework of beluga and caribou management. The migratory nature of both species presents a challenge, as their biophysical range extends beyond the jurisdiction of the ISR, thereby failing to adequately meet criteria for effective SES boundaries (Cox et al. 2010), and an analysis of the effectiveness of beluga or caribou management, as a whole, requires an assessment of numerous transboundary agreements and working groups (Adams et al. 1993, Ayles et al. 2002, Environment and Natural Resources 2011, Advisory Committee for the Cooperation on Wildlife Management 2014a). While these agreements occur beyond the scale of this research, their presence suggests that efforts to apply design principles at a large scale may need to focus on management activity beyond a specific governance area and on the range of the resource(s) in question. 


\section{Utility of a social-ecological system lens}

Using the SES framework to evaluate comanagement in the ISR by synthesizing existing data allows for a broad-scale assessment of harvest management. Assessing management via the presence of design principles showed the range of factors affecting subsistence harvesting, as well as the responses possible through the existing governing structure. This departs from previous studies in the ISR, which provide indepth examination of select components of the system, such as adaptive capacity, but do not apply a broader framework to the system at large (Berkes and Jolly 2001, Fast et al. 2005, Pearce et al. 2011). When examined through an SES lens, it becomes clear that the governance of the ISR is well equipped to translate observed changes into governance response but is still dependent on the outcomes of larger transboundary agreements (Adams et al. 1993, Adamczewski et al. 2009, Environment and Natural Resources 2011). While these agreements are not analyzed in this research, their presence indicates the potential for difficulties in scaling up the application of design principles to large-scale resources where ecological boundaries extend beyond clearly defined management boundaries (Berkes 2006).

While conclusions such as these are echoed in other studies (Olsson et al. 2005, Berkes 2006), they support the application of institutional design principles to larger study areas and cooperatively managed resources. Ostrom (2009) notes that large territories are less likely to be self-organized, and research on local adaptive management highlights the ability of areas with smaller boundaries to collectively manage natural resources (Olsson et al. 2005). However, the governing structure of the ISR clearly reflected the nested enterprises found in successful SES governance, and analysis of Inuvialuit management of caribou and beluga revealed the strong presence of institutional design principles (Table 4). These results support a growing movement to incorporate Ostrom's design principles beyond their original intent, using them in the analysis of large-scale common-pool resources (Cox 2014).

These results have additional implications for comanagement throughout the Canadian Arctic. Multiple indigenous communities are tasked with comanaging wildlife harvesting in large treaty areas across the Canadian Arctic (Dowsley 2009, Armitage et al. 2011, Dale and Armitage 2011) at a scale that is largely unaddressed in previous SES research. This study shows that design principles can be effective in understanding the functioning of large-scale common-pool resource governance, while also suggesting that in order to fully understand the management of resources that span multiple boundaries, an analysis of the resource management network may be more effective than focusing on a single region.

\section{CONCLUSION}

Comanagement of subsistence harvesting in the ISR displays a multitude of design principles commonly found in successful SESs. The IFA clearly defines the boundaries of the user group and resource area, and provides a framework for nested enterprises within the ISR. Strong linkages between these actor groups allow for efficient translation of observation into policy action, as local observation and scientific knowledge are readily incorporated into management (Fig. 1). While this analysis is limited in that it does not analyze the structure of transboundary management efforts surrounding each species, it does indicate the applicability of institutional design principles across a large resource area and highlights effective integration of design principles originally thought to be indicative of small-scale common-pool management systems (Ostrom 1990). This is important, as wildlife harvest management in the ISR has not previously been analyzed using this framework, and the clear presence of design principles in a large comanaged system supports the increased use of this framework for understanding large-scale social-ecological systems.

Responses to this article can be read online at: http://www.ecologyandsociety.org/issues/responses. $\mathrm{php} / 8960$

Acknowledgments:

This paper benefited greatly from the advice, review, and editing of Dr. Natalie Ban, and the time and edits of two anonymous reviewers.

\section{LITERATURE CITED}

Adamczewski, J., J. Boulanger, B. Croft, D. Cluff, B. Elkin, J. Nishi, A. Kelly, A. D’Hont, and C. Nicoloson. 2009. Decline in the Bathurst caribou herd 2006-2009: a technical evaluation of field data and modeling.

Adams, M., K. J. Frost, and L. A. Harwood. 1993. Alaska and Inuvialuit Beluga Whale Commission (AIBWC): an initiative in "at home management". Arctic 46(2):134-137. http://dx.doi. org/10.14430/arctic1334

Advisory Committee for the Cooperation on Wildlife Management. 2014a. Taking care of caribou: the Cape Bathurst, Bluenose-West, and Bluenose-East barren-ground caribou herds management plan. Yellowknife, Northwest Territories, Canada.

Advisory Committee for the Cooperation on Wildlife Management. 2014b. We have been living with caribou all our lives: a report on information recorded during community meetings for "Taking care of caribou: the Cape Bathurst, Bluenose-West, and Bluenose-East barren-ground caribou herds management plan". Yellowknife, Northwest Territories, Canada.

Alunik, I., E. Kolausok, and D. Morrison. 2003. Across time and tundra: the Inuvialuit of the western Arctic. Raincoast Books, Vancouver, British Columbia, Canada.

Andrachuk, M., and B. Smit. 2012. Community-based vulnerability assessment of Tuktoyaktuk, NWT, Canada to environmental and socio-economic changes. Regional Environmental Change 12(4):867-885. http://dx.doi.org/10.1007/s10113-012-0299-0

Armitage, D., F. Berkes, A. Dale, E. Kocho-Schellenberg, and E. Patton. 2011. Co-management and the co-production of knowledge: learning to adapt in Canada's Arctic. Global Environmental Change 21:995-1004. http://dx.doi.org/10.1016/j. gloenvcha.2011.04.006

Ayles, G. B., R. Bell, and H. Fast. 2002. The Beaufort Sea Conference 2000 on the renewable marine resources of the Canadian Beaufort Sea. Arctic 55(5):iii-v. http://dx.doi. org/10.14430/arctic729 
Bell, R. K., and L. A. Harwood. 2012. Harvest-based monitoring in the Inuvialuit Settlement Region: steps for success. Arctic 65 (4):421-432. http://dx.doi.org/10.14430/arctic4240

Bennett, T. 2012. Monitoring environmental conditions using participatory photo-mapping with Inuvialuit knowledge holders in the Mackenzie Delta Region, Northwest Territories. University of Victoria, Victoria, British Columbia, Canada.

Berkes, F. 1999. Sacred ecology. Taylor and Francis, Philadelphia, USA and London, UK.

Berkes, F. 2006. From community-based resource management to complex systems: the scale issue and marine commons. Ecology and Society 11(1):45. http://dx.doi.org/10.5751/es-01431-110145

Berkes, F. 2009. Evolution of co-management: role of knowledge generation, bridging organizations and social learning. Journal of Environmental Management 90(5):1692-1702. http://dx.doi. org/10.1016/j.jenvman.2008.12.001

Berkes, F., and H. Fast. 2005. Introduction. In F. Berkes, R. Huebert, H. Fast, M. Manseau, and A. Diduck, editors. Breaking ice renewable resource and ocean management in the Canadian north. University of Calgary Press, Calgary, Alberta, Canada.

Berkes, F., and D. Jolly. 2001. Adapting to climate change: socialecological resilience in a Canadian western Arctic community. Conservation Ecology 5(2):18. http://dx.doi.org/10.5751/es-00342-050218

Burn, C. R., and S. V. Kokelj. 2009. The environment and permafrost of the Mackenzie Delta area. Permafrost and Periglacial Processes 20(2):83-105. http://dx.doi.org/10.1002/ ppp. 655

Carlsson, L., and F. Berkes. 2005. Co-management: concepts and methodological implications. Journal of Environmental Management 75(1):65-76. http://dx.doi.org/10.1016/j.jenvman.2004.11.008

Carter, B. T. G., and E. A. Nielsen. 2011. Exploring ecological changes in Cook Inlet beluga whale habitat through traditional and local ecological knowledge of contributing factors for population decline. Marine Policy 35:299-308. http://dx.doi. org/10.1016/j.marpol.2010.10.009

Cobb, D., H. Fast, M. H. Papst, D. Rosenberg, R. Rutherford, and J. E. Sareault. 2008. Beaufort Sea Large Ocean Management Area: ecosystem overview and assessment report. Canadian Technical Report of Fisheries and Aquatic Sciences 2780.

Cohen, S. J. 1997. What if and so what in northwest Canada: could climate change make a difference to the future of the Mackenzie Basin? Arctic 50(4):293-307. http://dx.doi.org/10.14430/ arctic1112

Corell, R. W. 2006. Challenges of climate change: an Arctic perspective. AMBIO 35(4):148-152. http://dx.doi.org/10.1579/0044-7447 (2006)35[148: coccaa]2.0.co;2

Cox, M. 2014. Understanding large social-ecological systems: introducing the SESMAD project. International Journal of the Commons 8(2):265-276. http://dx.doi.org/10.18352/ijc.406

Cox, M., G. Arnold, and S. V. Tomás. 2010. A review of design principles for community-based natural resource management. Ecology and Society 15(4):38. [online] URL: http://www. ecologyandsociety.org/vol15/iss4/art38/
Dale, A., and D. Armitage. 2011. Marine mammal comanagement in Canada's Arctic: knowledge co-production for learning and adaptive capacity. Marine Policy 35:440-449. http:// dx.doi.org/10.1016/j.marpol.2010.10.019

Day, B. 2002. Renewable resources of the Beaufort Sea for our children; perspectives from an Inuvialuit elder. Arctic 55(5). http:// dx.doi.org/10.14430/arctic 730

Department of Indian and Northern Affairs Canada. 1984. The western Arctic claim: the Inuvialuit Final Agreement.

Dowsley, M. 2009. Community clusters in wildlife and environmental management: using TEK and community involvement to improve co-management in an era of rapid environmental change. Polar Research 28(1):43-59. http://dx.doi. org/10.1111/j.1751-8369.2008.00093.x

Dressler, W. H., F. Berkes, and J. Mathias. 2001. Beluga hunters in a mixed economy: managing the impacts of nature-based tourism in the Canadian western Arctic. Polar Record 37(200):3548. http://dx.doi.org/10.1017/s0032247400026735

Environment and Natural Resources. 2011. Caribou forever-our heritage, our responsibility: a barren-ground caribou management strategy for the Northwest Territories 2011-1015. Northwest Territories, Canada.

Fast, H., D. B. Chiperzak, K. J. Cott, and G. M. Elliot. 2005. Integrated management planning in Canada's western Arctic: an adaptive consultation process. In F. Berkes, R. Huebert, H. Fast, M. Manseau, and A. Diduck, editors. Breaking ice renewable resource and ocean management in the Canadian north. University of Calgary Press, Calgary, Alberta, Canada.

Fidler, C., and B. F. Noble. 2013. Stakeholder perceptions of current planning, assessment and science initiatives in Canada's Beaufort Sea. Arctic 66(2):179-190. http://dx.doi.org/10.14430/ $\underline{\operatorname{arctic} 4289}$

Fisheries Joint Management Committee (FJMC). 2001. Beaufort Sea beluga management plan. Fisheries Joint Management Committee.

Fleischman, F. D., N. C. Ban, L. S. Evans, G. Epstein, G. GarciaLopez, and S. Villamayor-Tomas. 2014. Governing large-scale social-ecological systems: lessons from five cases. International Journal of the Commons 8(2):428-456. http://dx.doi.org/10.18352/ ijc. 416

Government of Northwest Territories (GNWT). 2008. NWT climate change impacts and adaptation report. Government of Northwest Territories, Yellowknife, Northwest Territories, Canada.

Gunn, A., C. J. Johnson, J. S. Nishi, C. J. Daniel, D. E. Russell, M. Carlson, and J. Z. Adamczewski. 2011. Understanding the cumulative effects of human activities on barren-ground caribou. In P. R. Krausman and L. K. Harris, editors. Cumulative effects in wildlife management: impact mitigation. CRC Press. http://dx. doi.org/10.1201/b10788-11

Harwood, L. A., P. Norton, B. Day, and P. A. Hall. 2002. The harvest of beluga whales in Canada's western Arctic: hunterbased monitoring of the size and composition of the catch. Arctic 55(1):10-20. http://dx.doi.org/10.14430/arctic687 
Harwood, L. A., and T. G. Smith. 2001. Whales of the Inuvialuit Settlement Region in Canada's western Arctic: an overview and outlook. Arctic 55(Supplement 1: The Beaufort Sea Conference 2000 on the Renewable Marine Resources of the Canadian Beaufort Sea):77-93.

Inuvialuit Inupiat Beaufort Sea Beluga Whale Agreement. 2000.

Johnson, C., M. Boyce, R. Case, H. D. Cluff, R. Gau, A. Gunn, and R. Mulders. 2005. Cumulative effects of human development on Arctic wildlife. Wildlife Monographs 160.

Joint Secretariat. 2003. Inuvialuit harvest study: data and methods report 1988-1997. Inuvik, Northwest Territories, Canada.

Kocho-Schellenberg, J.-E., and F. Berkes. 2015. Tracking the development of co-management: using network analysis in a case from the Canadian Arctic. Polar Record 51(04):422-431. http:// dx.doi.org/10.1017/s0032247414000436

Kofinas, G. P. 2005. Caribou hunters at the co-management interface: emergent dilemmas and the dynamics of legitimacy in power sharing. Anthropologica 47(2):179-196.

Krupnik, I., and G. C. Ray. 2007. Pacific walruses, indigenous hunters, and climate change: bridging scientific and indigenous knowledge. Deep Sea Research Part II: Topical Studies in Oceanography 54(23-26):2946-2957. http://dx.doi.org/10.1016/j. dsr2.2007.08.011

Lacroix, K., and G. Richards. 2015. An alternative policy evaluation of the British Columbia carbon tax: broadening the application of Elinor Ostrom's design principles for managing common-pool resources. Ecology and Society 20(2):38. http://dx. doi.org/10.5751/ES-07519-200238

Nagy, J. A., and D. Johnson. 2006. Estimates of the number of barren-ground caribou in the Cape Bathurst and Bluenose-West herds and reindeer/caribou on the Upper Tuktoyaktuk Peninsula derived using post calving photography July 2006. Government of the Northwest Territories, Department of Environment and Natural Resources, Yellowknife, Northwest Territories, Canada.

Nellemann, C., and R. D. Cameron. 1998. Cumulative impacts of an evolving oil-field complex on the distribution of calving caribou. Canadian Journal of Zoology 76(8):1425-1430. http://dx. doi.org/10.1139/z98-078

Nuttall, M. 2006. The Mackenzie Gas Project. Indigenous affairs. International Work Group for Indigenous Affairs.

Olsson, P., C. Folke, and F. Berkes. 2005. Adaptive comanagement for building resilience in social-ecological systems. Environmental Management 34(1):75-90. http://dx.doi.org/10.1007/s00267-003-0101-7

Ostrom, E. 1990. Governing the commons: the evolution of institutions for collective action. Cambridge University Press, New York, USA.

Ostrom, E. 2009. A general framework for analyzing sustainability of social-ecological systems. Science 325 (5939):419-422. http://dx.doi.org/10.1126/science.1172133

Pearce, T., J. D. Ford, F. Duerden, B. Smit, M. Andrachuk, L. Berrang-Ford, and T. Smith. 2011. Advancing adaptation planning for climate change in the Inuvialuit Settlement Region (ISR): a review and critique. Regional Environmental Change 11 (1):1-17. http://dx.doi.org/10.1111/j.1751-8369.2008.00094.x

Pearce, T., J. D. Ford, G. J. Laidler, B. Smit, F. Duerden, M. Allarut, M. Andrachuk, S. Baryluk, A. Dialla, P. Elee, A. Goose, T. Ikummaq, E. Joamie, F. Kataoyak, E. Loring, S. Meakin, S. Nickels, K. Shappa, J. Shirley, and J. Wandel. 2009. Community collaboration and climate change research in the Canadian Arctic. Polar Research 28(1):10-27.

Pearce, T., B. Smit, F. Duerden, J. D. Ford, A. Goose, and F. Kataoyak. 2010. Inuit vulnerability and adaptive capacity to climate change in Ulukhaktok, Northwest Territories, Canada. Polar Record 46(2):157-177. http://dx.doi.org/10.1017/ s0032247409008602

Pollnac, R., P. Christie, J. E. Cinner, T. Dalton, T. M. Daw, G. E. Forrester, N. A. J. Graham, and T. R. McClanahan. 2010. Marine reserves as linked social-ecological systems. Proceedings of the National Academy of Sciences of the United States of America 107(43):18262-18265. http://dx.doi.org/10.1073/pnas.0908266107

Schlag, M., and H. Fast. 2003. Marine stewardship \& Canada's oceans agenda in the western Canadian Arctic: a role for youth. In F. Berkes, R. Huebert, H. Fast, M. Manseau, and A. Diduck, editors. Breaking ice renewable resource and ocean management in the Canadian north. University of Calgary Press, Calgary, Alberta, Canada.

Usher, P. J. 2002. Inuvialuit use of the Beaufort Sea and its resources, 1960-2000. Arctic 55(Supp. 1):18-28. http://dx.doi. org/10.14430/arctic732

Working Group on the General Status of NWT Species. 2011. NWT species 2011-2014 - general status ranks of wild species in the Northwest Territories. Government of the Northwest Territories, Department of Environment and Natural Resources, Yellowknife, Northwest Territories, Canada. 